\title{
SUPERIOR RESPONSIBILITY IN THE BEMBA Case - Analysis of the Court's Findings on NeCESSARY and Reasonable Measures ${ }^{1}$
}

\author{
Michala Chadimová \\ Faculty of Law, Palacký University Olomouc, Czech Republic \\ MichalaChadimova@seznam.cz
}

CHADIMOVA, Michala. Superior Responsibility in the Bemba Case - Analysis of the Court's Findings on Necessary and Reasonable Measures. International and Comparative Law Review, 2019, vol. 19, no. 2, pp. 300-312. DOI: 10.2478/ iclr-2019-0026.

\begin{abstract}
Summary: This article critically analyses an interpretation and application of necessary and reasonable measures to prevent or repress crimes committed by the subordinates in the Bemba case. The aim of the Article is to analyse the Pre-Trial Chamber, Trial Chamber and Appeal Chamber findings on necessary and reasonable measures in connection to responsibility of person effectively acting as a military commander. In doing critically analyses of the interpretation and application, this article evaluates legal challenges faced by the ICC in using superior responsibility, with special focus on the relevance of motives behind the measures taken by a superior or commander and the issue of remote commander. This study provides first comprehensive analysis of necessary and reasonable measures requirement in the Bemba case and as such, offers the latest development on the superior responsibility doctrine applicable at the ICC.
\end{abstract}

Keywords: Superior responsibility, Bemba case, necessary and reasonable measures, remote commander, relevance of motives

\section{Introduction}

Superior responsibility is firmly established within customary international law and as such, it is reflected in founding documents of all ad hoc international tribunals, hybrid tribunals and also the International Criminal Court (ICC). ${ }^{2}$ In 2016, the Trial Chamber (TCH) of the ICC found Bemba guilty of crimes

1 The present article is an outcome of the project International Criminal Responsibility for Special Intent Crimes, project number IGA_PF_2019_010, supported by the Internal Grant Agency of the Palacky University in Olomouc.

2 The terms superior and command have been historically employed in different context, particularly to distinguish between a military superior - commander and a civilian superior. The term command responsibility gives a more accurate impression of the origin and purpose of the doctrine, whereas the term superior responsibility has been preferred during the last decade because of its neutrality, referring to both civilian and military superiors. However, unless otherwise specified, the author employs the term superior responsibility and commander responsibility interchangeable. 
against humanity and war crimes committed by his troops in the Central African Republic (CAR) from 2002-2003 and sentenced him to 18 years imprisonment. This was ground breaking decision. Bemba was first person, and so far the only one, sentenced by the ICC on the basis of superior responsibility. Nevertheless, in 2018, the Appeals Chamber (ACH) reversed that decision and acquitted Bemba of all charges. This is the final judgment in the Bemba case, the judgment which caused controversy and confusion as the judges of the ACH decided by a narrow majority of $3 / 2 .^{3}$

The ACH judgment touches upon several controversial aspects, such as standard of review or standard of threshold for confirmation of charges decision. In author's view, these aspects have so far shielded discussion on the substantial finding concerning superior responsibility and its development in the case. This is the reason why the author decided to focus her analysis of the Bemba case solely on the key issue of necessary and reasonable measures within a superior responsibility. By using a qualitative research as a method of inquiry, this study critically analyses an interpretation and application of necessary and reasonable measures to prevent or repress conducted by three different Chambers of the ICC - the PTCH II, the TCH and the ACH. ${ }^{4}$ In doing critically analyses of the application, this study will point out legal challenges and obstacles emerging from the Bemba case. The importance will be given to the issue of the motive behind Bemba's measures and Bemba remoteness, as these aspects are sometimes suggested as the key issue within superior responsibility leading to his acquittal.

The Bemba case has received worldwide attention for a reason. This case may determine the direction of other cases in which the prosecution seeks the conviction on the basis of superior responsibility. Unfortunately, up until today, there is no complex analysis on necessary and reasonable measures in the Bemba case. ${ }^{5}$ This article aims to analyze decision of the PTCH II and both judgments and determine what legal precedent it might level for future applicability of superior responsibility at the ICC.

3 It is interesting to note that the ACH's judgment itself has 80 pages but the Dissenting Opinion of Judge Sanji Mmasenono Monageng and Judge Piotr Hofmański has 269 pages, Concurring Separate Opinion of Judge Eboe-Osuji has 117 pages and Separate opinion Judge Christine Van den Wyngaert and Judge Howard Morrison has 34 pages.

4 Including Dissenting Opinion of Judge Sanji Mmasenono Monageng and Judge Piotr Hofmański, Concurring Separate Opinion of Judge Eboe-Osuji and Separate opinion Judge Christine Van den Wyngaert and Judge Howard Morrison.

5 The analysis done by Miles Jackson on two issues within the necessary and reasonable measures is highly valuable, including some comments of Michael Karnavas. JACKSON, Miles. Commanders' Motivations in Bemba. EJIL: Talk! Blog of the European Journal of International Law. 15. 7. 2018. [online]. Available at: https://www.ejiltalk.org/commanders-motivations-in-bemba/. Accessed 27.01.2019. JACKSON, Miles. Geographical Remoteness in Bemba. EJIL: Talk! Blog of the European Journal of International Law. 30. 7. 2018. [online]. Available at: https://www.ejiltalk.org/geographical-remoteness-in-bemba/. Accessed 7.2.2019. 


\section{Court's findings on necessary and reasonable measures to prevent or repress}

Under superior responsibility, it is necessary to prove that the superior failed to fulfil at least one of the three duties listed under Article 28 of the Statute. It has to be proven that the superior failed to prevent a crime, failed to repress crimes or failed to submit the matter to the competent authorities for investigation and prosecution. ${ }^{6}$ The key issue in Bemba case came down to whether Bemba took the necessary and reasonable measures to prevent or repress the commission of the crimes or to submit them to the competent authorities for investigation and prosecution. $^{7}$

\subsection{Pre-Trial Chamber's Findings}

Article 28 of the Statute does not define any specific measures required by the duty to prevent crimes. Nevertheless, the PTCH II presented some factors that could be taken as such measures. According the PTCH II, the duty to prevent encompasses the duty to (i) ensure adequate training in international humanitarian law; (ii) to secure reports that all military actions were carried out in accordance with international law; (iii) to issue orders aiming at bringing the relevant practices into accord with the rules of war; and (iv) to take disciplinary measures to prevent the commission of atrocities by the troops under the superior's command. ${ }^{8}$ In this manner, the PTCH II referred to the ICTY jurisprudence - especially the Strugar and Hadžihasanović/Kubura cases. ${ }^{9}$

The PTCH II held that submitting the matter to competent authorities "remedies a situation where commanders do not have the ability to sanction their forces". ${ }^{10}$ According the PTCH II, this includes circumstances where the superior has the ability to take measures, yet those measures do not seem to be adequate. ${ }^{11}$ There has been a discussion whether this finding suggests that the duty to repress and the duty to submit the matter to the competent authorities for investigation and prosecution are alternative, rather than distinct obligations. ${ }^{12}$ The author does not share this opinion and does not find anything in the PTCH

6 Article 28 of the Rome Statute. Although the Statute uses alternative language ("or") it is clear that failure to discharge any of these duties may attract criminal liability.

7 The actus reus for superior responsibility is based on omission - the failure to prevent or punish the crimes of subordinates.

8 Bemba, ICC, ICC-01/05-01/08 424. Decision Pursuant to Article 61(7)(a) and (b) of the Rome Statute, PTCH II, 3. 7. 2009, $\$ 438$. Hereinafter referred to as Bemba, Decision Pursuant to Article 61(7)(a) and (b) of the Rome Statute. $\$ 438$.

9 Štrugar, ICTY, IT-01-42-T, TCH, 31. 1. 2005, §374. Hadžihasanović/Kubura, IT-01-47-A, ICTY, ACH, 22. 4. 2008. \$153.

10 Bemba, Decision Pursuant to Article 61(7)(a) and (b) of the Rome Statute, $₫ 442$.

11 Ibid.

12 Making Sense of Command Responsibility. Amnesty International. Opinion. 8. 10. 2018. [online]. Available at: https://hrij.amnesty.nl/making-sense-of-command-responsibilitybemba/. Accessed 22. 1. 2019. 
II decision that would expressly lead to this conclusion. The duty to repress as set up in Article 28 of the Rome Statute thus encompasses two separate duties arising at two different stages of the commission of crimes. ${ }^{13}$ Firstly, the duty to repress includes a duty to stop ongoing crimes. This includes the obligation to stop a possible chain effect, which may lead to other similar crimes. Secondly, the duty to repress includes an obligation to punish forces after the commission of crimes. ${ }^{14}$ The duty to punish may be fulfilled in two different ways - either by the superior himself taking the necessary and reasonable measures to punish his forces, or, by referring the matter to the competent authorities. Thus, the duty to punish (which represents a part of the duty to repress) constitutes a distinct to the third duty mentioned under Article 28 of the Statute - a duty to submit the matter to the competent authorities, when the superior is not himself in a position to take necessary and reasonable measures to punish.

The PTCH II also noted that "what constitutes a reasonable and necessary measure will be assessed on the basis of the commander's de jure power as well as his de facto ability to take such measures". ${ }^{15}$ Thus, the PTCH II expressly stated that the reasonable and necessary measures taken or the ones that should have been taken cannot be analyzed separately, but this analysis must be done in connection to effective control requirement and material ability to take such a measures.

\subsection{Trial Chamber's Findings}

The TCH III concluded that the duty to prevent encompasses the duty to stop crimes that are about to be committed or crimes that are being committed. It was clarified that the duty to prevent can arise before the commission of a crime but also during the commission. ${ }^{16}$ In the Bemba, the TCH III also noted that the statutes of the ad hoc tribunals do not make reference to a duty to 'repress' but use the terms 'to prevent or to punish. ${ }^{17}$ The TCH III clarified that the notion of 'repress' overlaps the duty of prevention to a certain degree, particularly in terms of the duty to prevent crimes in progress and crimes which involve ongoing elements being committed over an extended period. ${ }^{18}$ The TCH III found that Bemba took "a few measures" in response to allegations of crimes committed by MLC troops in the CAR and those were all limited "[..] in mandate, execution, and/or results." ${ }^{\prime 19}$ According the TCH III, the measures taken were inadequate and their inadequacy was "aggravated" by indications that they were not "genuine". ${ }^{20}$ The TCH III noted that the "[...] measures were primarily moti-

13 TRIFFTERER, O.: supra, 2002, p. 201.

14 Bemba, Decision Pursuant to Article 61(7)(a) and (b) of the Rome Statute, $\$ 439$.

$15 B e m b a$, Decision Pursuant to Article 61(7)(a) and (b) of the Rome Statute, $\$ 443$.

16 Bemba, $\$ 202$.

17 Ibid, $\$ 206$.

18 Ibid, $\$ \$ 205-206$.

$19 \mathrm{Ibid}, \$ \$ 719-720$.

20 Ibid, $\$ 727$. 
vated by Mr Bemba's desire to counter public allegations and rehabilitate the public image of the MLC". ${ }^{21}$ The TCH III expressly mentioned specific measures Bemba could have taken in order to fulfil his duty to conduct necessary and reasonable measures. ${ }^{22}$ Further, the Chamber emphasizes that one key measure at Bemba's disposal was withdrawal of the MLC troops from the CAR. The TCH III considered that he had the ability to withdraw the troops in November 2002. However, it was not until March 2003 that the MLC troops were withdrawn on Bemba's order. Moreover, the motivations in withdrawing the troops were only political. ${ }^{23}$ The TCH III furthermore noted that Bemba had ultimate disciplinary authority over the MLC contingent in the CAR, but failed to empower the full and adequate investigation and prosecution of allegations of crimes internally within the MLC and made no effort to refer the matter to the CAR authorities, or cooperate with international efforts to investigate the crimes. ${ }^{24}$

The TCH III does not provide analysis concerning challenges rising from Bemba's remote location in determining that he had failed to take necessary and reasonable measures. However, in a section on causation the TCH III held that "despite his remote location, $\mathrm{Mr}$ Bemba had the authority and ability to take measures to prevent and repress the commission of crimes". ${ }^{25}$

In conclusion, the TCH III ultimately found that Bemba failed to take "[...] all necessary and reasonable measures within his power to prevent or repress the commission of crimes by his subordinates during the 2002-2003 CAR Operation, or to submit the matter to the competent authorities". ${ }^{26}$ The TCH III provided analysis of measures that Bemba took in response to allegations of crimes committed by MLC troops in the CAR. The TCH III went on in addressing their limits in mandate, execution and results. The TCH III also expressly mentioned specific measures Bemba could have taken in order to fulfil his duty to conduct necessary and reasonable measures. On a top of those findings, the TCH III emphasised that the inadequateness of the measures was aggravated by motives of Bemba.

\subsection{Appeals Chamber's Findings - Majority}

The ACH disagreed with the TCH's findings and concluded that Bemba took all necessary and reasonable measures within his power to prevent or repress the commission of crimes by his subordinates during the 2002-2003 CAR Operation.

21 Ibid, $\$ 728$.

22 Ibid, $\$ 729$.

23 Ibid, $\$ 730$.

24 Ibid, $\$ 733$.

25 Ibid, $\$ 738$.

26 Ibid, $\$ 734$. 
The majority finds that the TCH III paid insufficient attention to the fact that the MLC troops were operating in a foreign country and the difficulties on Bemba's ability to take measures; ${ }^{27}$ treated Bemba's motivations as determinative of the adequacy of the measures; ${ }^{28}$ and failed to establish that Bemba purposively limited the mandates of the commissions and inquiries. ${ }^{29}$ In assessing reasonableness, the $\mathrm{ACH}$ referred to the operational realities on the ground at the time faced by the commander. ${ }^{30}$ The $\mathrm{ACH}$ held that it needs to be proved that the commander did not take specific and concrete measures that were available to him or her and which a reasonably diligent commander in comparable circumstances would have taken. In the view of $\mathrm{ACH}$, the TCH III must specifically identify what a commander should have done in concreto. On the other hand, it is not the responsibility of the accused to show that the measures he or she did take were sufficient. ${ }^{31}$ As well, it is not a commander's duty to take each and every possible measure at his or her disposal. A commander may take into consideration the impact of measures to prevent or repress criminal behavior on ongoing or planned operations and may choose the least disruptive measure as long as it can reasonably be expected that this measure will prevent or repress the crimes. ${ }^{32}$ The $\mathrm{ACH}$ also considered that most of the criminal incidents took part at the beginning of the 2002-2003 CAR Operation, whereas little evidence was presented regarding specific criminal acts towards the end of the operation. According the $\mathrm{ACH}$, this should have been taken into account. ${ }^{33}$ The $\mathrm{ACH}$ did not discuss whether withdrawal of troops would be considered as a reasonable measure. It has been only discussed that Document Containing the Charges did not specifically identify the redeployment of troops as a necessary and reasonable measure that Bemba should have taken. As such, Bemba was not sufficiently notified of this factual allegation as a necessary and reasonable measure. ${ }^{34}$

The majority of the ACH also referred to the consideration of Bemba's motivations. ${ }^{35}$ According the $\mathrm{ACH}$, the TCH III erred because it took into consideration that is an irrelevant factor. ${ }^{36}$ The $\mathrm{ACH}$ also held that it would have to be proved that Bemba purposively limited the mandates of the commissions and inquiries in order to attribute the insufficiency of the measures. ${ }^{37}$ It was argued by the ACH that the TCH III appears to have lost sight of the fact that the meas-

27 Bemba, ICC, ICC-01/05-01/08 A, ACH, 8. 7. 2018, $\$ 171$. Hereinafter referred to as Bemba Appeals Chamber Judgement.

28 Ibid, $\$ 178$.

29 Ibid, $\$ 181$.

30 Ibid, $\$ 170$.

31 Ibid.

32 Ibid.

33 Ibid, $\$ 184$.

34 Ibid, $\$ 187$.

35 Ibid, $\$ 178$.

36 Ibid, $\$ 179$.

37 Ibid, $\$ 181$.

Published by Palacký University Olomouc, Czech Republic, 2019.

ISSN (print): 1213-8770; ISSN (online): 2464-6601 
ures taken by a commander cannot be faulted merely because of shortfalls in their execution. ${ }^{38}$ And, it held that "the Trial Chamber's error in considering Mr Bemba's motivation had a material impact on the entirety of its findings on necessary and reasonable measures because it permeated the Trial Chamber's assessment of the measures that Mr Bemba had taken." ${ }^{39}$

On the status of Bemba as a remote commander, the majority judgment makes use of a similar formulation on a number of occasions. ${ }^{40}$ It held that "the Trial Chamber failed to appreciate that, as a remote commander, Mr Bemba was not part of the investigations and was not responsible for the results generated [...]" 41 and "[...] Trial Chamber paid insufficient attention to the fact that the MLC troops were operating in a foreign country with the attendant difficulties on Mr Bemba's ability, as a remote commander, to take measures." ${ }^{42} \mathrm{Nev}$ ertheless, the majority itself fails to set out comprehensively those limitations or explain in detail why the TCH III had reached the wrong conclusion in this regard. ${ }^{43}$ It is not clear whether the majority has made a distinction between remote commander and commander present at the grounds and whether there are different sets of requirements for both categories. President's Separate Concurring Opinion suggest that the findings of majority should be interpreted as a factor all of its own, which would not necessarily insulate perpetrators from criminal responsibility. The President presented that " $[\mathrm{G}]$ geographic remoteness is only a factor to be considered among other circumstances or peculiarities of a given case. It serves its greatest value in the assessment of what is reasonable as a measure to prevent or repress violations to submit them to competent authorities for investigation and prosecution." ${ }^{44}$

Judge Eboe-Osuji in his Concurring Separate Opinion stressed that any measure that is not feasible in all of the cognizable circumstances would not be reasonable. ${ }^{45}$ Judge Eboe-Osuji did agree with the conclusion of the TCH III that withdrawal of troops is key among the range of measures that must come within a commander's duty to take all reasonable measures to prevent or repress the commission of crimes by subordinates or to submit the matter to the compe-

38 Ibid, $\$ 180$.

39 Ibid, $\$ 191$.

40 Ibid, $\$ \$ 191$. See also Ibid, $\$ \$ 171,189,191$, and 192.

41 Ibid, $\$ 192$.

42 Ibid, $\$ 171$.

43 See also Remoteness in itself cannot serve as a defence to command responsibility. Amnesty International. Opinion. 10. 10. 2018. [online]. Available at: https://hrij.amnesty.nl/remoteness-command-responsibility-icc/. Accessed 20.1.2019.

44 Bemba, ICC, ICC-01/05-01/08-3636-Anx2, ACH, 8. 7. 2018, §258. Hereinafter referred to Bemba Separate Opinion.

45 Bemba, ICC, ICC-01/05-01/08-3636-Anx3, ACH, 8. 7. 2018, $\$ 271$. Hereinafter referred to as Bemba Concurring separate opinion. 
tent authorities. ${ }^{46}$ Nevertheless, he concluded that in the factual circumstances of the case, the duty to withdraw does not affect the outcome of the appeal. ${ }^{47}$

\subsection{Appeals Chamber's Findings - Minority}

There are several interesting remarks made by the dissenting judges in response to the assessment of a necessary and reasonable measure by the majority. The Dissenting Judges agreed that the motives of a commander are not always irrelevant to the assessment of "necessary and reasonable measures". However, the TCH III did not state, as the majority claims, that "these motivations were a factor 'aggravating' the failure to exercise his duties" and did not employ the concept of an "aggravated omission" assessed by the majority. Nothing in the TCH's judgment indicates that Bemba's motivations were a "key factor" in, or "significantly affected" the TCH's assessment of the measures that Bemba took. ${ }^{48}$ The Dissenting Judges concluded that the majority has misinterpreted the TCH III findings to the motives of the commander. ${ }^{49}$

Furthermore, dissenting judges expressed opinion on the remoteness of commander and its treatment by the majority of the $\mathrm{ACH}$. Dissenting judges held that "[...] remoteness of the commander is part of the factual considerations that the Trial Chamber must assess in order to determine whether the accused had the material ability to prevent, repress or report the commission of crimes. As such, it suggests that the remoteness of a commander may be a relevant fact rather than the basis of a legal distinction. ${ }^{50}$

The dissenting judges also points out that the majority decision comes from losing sight of article 28 of the Rome Statute. The dissenting judges stressed that the manner the majority interpreted requirement of a necessary and reasonable measure suggests that a commander is responsible for not his failures but for his actions..$^{51}$ Minority found that this is evident in faulting the TCH III for failing to make findings as to whether he purposively limited the mandates of the commissions and inquiries that he set up. ${ }^{52}$ The Dissenting Judges held that Bemba failed specify how actual measures that he took or attempted to take to investigate MLC crimes on the CAR territory were affected by the limitations to which he alludes. ${ }^{53}$ As such, according the Dissenting Judges, the TCH III reasonably

46 Bemba Concurring separate opinion, $\$ 279$.

47 Bemba Concurring separate opinion, $\$ 282$.

48 Bemba Appeals Chamber Judgement, $\$ 178$.

49 Bemba, ICC, ICC-01/05-01/08-3636-Anx1-Red, ACH, 8. 7. 2018, \$182. Hereinafter referred to Bemba Dissenting opinion, $\$ \$ 70-78$.

50 JACKSON, Miles. Geographical Remoteness in Bemba. EJIL: Talk! Blog of the European Journal of International Law. 30. 7. 2018. [online]. Available at: https://www.ejiltalk.org/ geographical-remoteness-in-bemba/. Accessed 7. 2. 2019.

51 Bemba Dissenting opinion, $₫ 45$.

52 Bemba Dissenting opinion, $\$ 45$.

53 Bemba Dissenting opinion, $\$ 60-61$. 
assessed the evidence on this question and Bemba has not identified any error in the reasoning or conclusions of the TCH III such that would establish a misappreciation of the limitations on the MLC's jurisdiction and competence to investigate crimes in the CAR or Bemba's disciplinary authority over his troops. ${ }^{54}$ The author suggests that this more a question on the scope of evidence analyzed than a legal question. It seems rather unreasonable to require a proof he purposively limited the mandates of the commissions and inquiries that he set up. As discussed above, the motives behind Bemba actions behind the measures taken, is not determinative but only one of the factors that can be used in the assessment. Thus, there is no requirement to prove that Bemba purposively limited the mandates of the commissions and inquiries that he set up.

\section{Legacy of Bemba case}

The Bemba case is the first ICC case that employed superior responsibility as the only base for the defendant's responsibility. Despite its controversy, it naturally sets up conditions for the future applicability of superior responsibility at the ICC. The question is whether findings of the ACH in the Bemba case are binding for the future assessment by the Court in the upcoming cases employing superior responsibility. In contrast to the ad hoc Tribunals, Article 21 of the Rome Statute specifically sets out the applicable law for the Court. The Article also lays out a clear hierarchy of sources of law to be applied. On the other hand, the principles and rules of law as interpreted in previous Court's decisions may be applied but it is not compulsory. There is no hierarchy among the decisions of the ICC's three divisions. The use of precedent by the ICC thus far has not indicated that the Appeals Chamber rulings are superior to those of other chambers. As such, it can be concluded that the Chambers are not required to take into account finings in Bemba case, but may do so. Two issues have emerged in the analysis of necessary and reasonable measures that may play a role for future treatment of superior responsibility. Firstly, whether the motivation behind commander's decision is relevant and secondly, whether remoteness of the commander plays any role in the assessment of the measures taken and as such can avoid establishment of commander's responsibility.

\subsection{Relevance of motivation behind the commander's decision}

It is clear that the understanding of Bemba's motivations was critical to the assessment of the measures taken and led to Bemba's acquittal. The not problematic aspect is the basic rule into the adequateness of measures - an adequate measure remains adequate no matter the commander's motivation in taking it. This is not questioned, as majority and dissenting judges of the ACH seems to agree on this. ${ }^{55}$ Contrary, the commander's motivation in taking a measure may

54 Bemba Dissenting opinion, $\$ 60-61$.

55 Bemba Appeals Chamber Judgement, $\$ 176$. Bemba Dissenting opinion, $\$ 70$. 
be relevant, as a matter of evidence, to the determination of whether the measure was, in fact, genuine and thus adequate. ${ }^{56}$ However, the problematic aspect is in the majority's understanding of the TCH's treatment of Bemba's motivation. The key question is how the TCH III treated Bemba's motivations in its determination of whether he took all necessary and reasonable measures and whether the $\mathrm{ACH}$ interpreted the findings in a different way. Firstly, the TCH III set out the measures Bemba had taken and which he should have taken. ${ }^{57}$ Contrary to the majority findings, this analysis of the measures Bemba had taken and which he should have taken, seems to be done in concreto. The TCH III assessed that the taken measures were "grossly inadequate response to the consistent information of widespread crimes committed by MLC soldiers in the CAR". ${ }^{58}$ The majority of the appeal concluded that 'Trial Chamber's preoccupation with Bemba's motivations appears to have colored its entire assessment of the measures that he took.' This is not convincing as the TCH III has conducted the assessment of the measures taken, and subsequent assessment of measures that could have been taken. In the author's view, the TCH III did not treat motivations as determinative. Contrary, the majority's understanding of the TCH's treatment of Bemba's motivation seems out of step with the actual TCH's findings. As such, the motivation behind commander's decision may play a role but it should never be a determinative. The findings on the commander's motivation should be always preceded by analysis of measures taken, with its limits, and measures that should have been taken. Mere finding that measures were inadequate because the measures were purposively limited does not suffice. The conclusion of the $\mathrm{ACH}$ seems to come from misunderstanding of the TCH's findings. As such, the ACH's findings on the commander's motive don't bring a whole new concept and don't change how the motives should be assessed.

\subsection{Remoteness of the commander}

From reading the decision, it seems that no distinction between remote and no-remote in relation to assessment of measures taken (or the measure that should have been taken) was drawn nor contemplated drawing. ${ }^{59}$ As correctly noted by Jackson, the assumption that the remoteness would have made responding more difficult cannot hold across the full range of measures assessed by the TCH III, f. e. the mandates of two investigative commissions to allegations of

56 JACKSON, Miles. Commanders' Motivations in Bemba. EJIL: Talk! Blog of the European Journal of International Law. 15. 7. 2018. [online]. Available at: https://www.ejiltalk.org/ commanders-motivations-in-bemba/. Accessed 27.01.2019.

57 Bemba Appeals Chamber Judgement, $\$ 719$.

58 Ibid, $\$ 727$

59 See comment of Karnavas in discussion. JACKSON, Miles. Geographical Remoteness in Bemba. EJIL: Talk! Blog of the European Journal of International Law. 30. 7. 2018. [online]. Available at: https://www.ejiltalk.org/geographical-remoteness-in-bemba/. Accessed 7. 2. 2019 
pillage. ${ }^{60}$ Karnavas suggests that geography may play a role in the overall assessment of the facts and evidence into determination of a commander's awareness and any failures to act. He suggests that this assessment, taken into account a proper context - geography being one of the factors - was missing from the TCH's analysis. ${ }^{61}$ The author supports Karnavas's interpretation of the ACH Judgment. There is nothing in the ACH judgment and the Opinions suggesting interpretation supporting a distinction between requirements for reasonable and necessary measures for remote commander and no-remote commander. On the other hand, the reading suggests that remoteness of the commander is one of the factors that may play a role in the overall assessment of the facts and evidence into determination of a commander's effective control and any failures to act.

The issue of remote commander is even more connected to the requirement of effective control. The author argues that wording of remote commander points to the chain of command and effective control requirement. It is believed that there is no special requirement for a remote commander to fulfil in order to prove the effective control requirement or to ascertain the chain of command. As long as the superior-subordinate relationship can be proven (i.e. the chain of command) and there is effective control between the superior and commander, the requirement is satisfied. The author believes that the position of remote commander cannot automatically opt out the establishment of chain of command or effective control within the superior-subordinate, nor can call for prove of more intensive effective control of the commander over the troops. As the assessment of effective control is purely evidential dispute, it is hard to make determinative conclusion whether Bemba had the effective control over the MLC troops in the CAR without being personally present to all the hearings and the presentation of the evidence made by the prosecution and the defence. However, it seems that majority's requirement for higher or intensive effective control over the troops because of the remoteness of the commander is rather unsupported. Contrary, it might be indicia suggesting the lack of effective control (or missing chain of command) but this fact per se cannot opt out the possibility of retaining effective control. On the other hand, the remoteness of the commander can have limits on his or her ability to take necessary measures in order to prevent or repress the crimes committed by the subordinates.

60 JACKSON, Miles. Geographical Remoteness in Bemba. EJIL: Talk! Blog of the European Journal of International Law. 30. 7. 2018. [online]. Available at: https://www.ejiltalk.org/ geographical-remoteness-in-bemba/. Accessed 7. 2. 2019.

61 See comment of Karnavas in discussion. JACKSON, Miles. Geographical Remoteness in Bemba. EJIL: Talk! Blog of the European Journal of International Law. 30. 7. 2018. [online]. Available at: https://www.ejiltalk.org/geographical-remoteness-in-bemba/. Accessed 7. 2. 2019. 


\section{Conclusion}

At the end of the first ICC trial applying the unique definition of superior responsibility in Article 28 of the Rome Statute, interpretation and application of this provision is more confused than ever. The only unity between ACH's judges is when it comes to the conclusion that a necessary and reasonable measure is not primarily a matter of substantive law, but of evidence. As such, it must be determined on a case-by-case basis and therefore it depends on the specific circumstances of a given case. Although the findings are quite confusing and sometimes seems to be contradictory, Bemba case brings new light to Article 28 of the Rome Statute. Two main aspects analyzed in this article concerned the relevance of motive behind Bemba's measures and Bemba remoteness as a commander. After analysis of all findings, and given the fact that so far there is no established hierarchy among the decisions of the ICC's three divisions, the recommendation for treating the two aspects are as follows. As for the first one, the motivation behind commander's decision may play a role in the assessment but it should never be a determinative. The findings on the commander's motivation should be always preceded by analysis of measures taken, with its limits, and measures that should have been taken. Mere finding that measures were inadequate because the measures were purposively limited does not suffice. The author argues that the conclusion of the ACH seems to come from misunderstanding of the TCH's findings. As such, the ACH's findings on the commander's motive don't bring a whole new concept and don't change how the motives should be assessed. As for the second aspect, there should be no legal distinction between requirements for reasonable and necessary measures for remote commander and on the grounds present commander. The remoteness of the commander is one of the factors that may play a role in the overall assessment of the facts and evidence into determination of a commander's effective control and any failure to act. Remoteness of a commander also has to be assets in relation to effective control requirement. However, the remoteness itself should not be interpreted in any way as creating per se demand for higher or intensive effective control over the troops.

The final judgment in the Bemba case has definitely left some issues unsolved. However, when it comes to necessary and reasonable measures, the disagreement between each Chambers seems to be based on different interpretation of the evidence and misunderstanding of findings than disagreement on legal merits. This confusion is also enhanced by misunderstanding of the TCH's findings by the ACH. The ACH's decision has provoked discussion on several aspects but after careful analysis, it can be concluded that the case does not bring new elements or requirements for establishment that a commander has done all necessary and reasonable measures to prevent a crime, to repress crimes or to submit the matter to the competent authorities for investigation and prosecution. 


\section{References}

BROUWERS, M. P. W. (eds). The Law of superior Responsibility, Wolf Legal Publishers, 2012.

FROUVILLE, Olivier. Droit International Penal, Modalites de participation a la commission de l'infraction. Paris: A. Pedone, 2012, pp. 404-405.

JACKSON, Miles. Commanders' Motivations in Bemba. EJIL: Talk! Blog of the European Journal of International Law. 15. 7. 2018. [online] [27-01-2019]. Available at: https:// www.ejiltalk.org/commanders-motivations-in-bemba/

JACKSON, Miles. Geographical Remoteness in Bemba. EJIL: Talk! Blog of the European Journal of International Law. 30. 7. 2018. [online] [7-02-2019]. Available at: https:// www.ejiltalk.org/geographical-remoteness-in-bemba/

O'REILLY, Arthur Thomas. Superior responsibility: a call to realign doctrine with principles. American University International Law Review. 2004, vol. 20, no. 1.

SVAČEK Ondřej. CHADIMOVA, Michala. PROCHAZKOVA, Ivana. Superior responsibility in international criminal law. Praha: Leges, 2017.

TRIFFTERER, Otto. Commentary on the Rome Statute of the International Criminal Court: observers' notes, article by article. München: Beck, 2008. p. 301.

Remoteness in itself cannot serve as a defence to command responsibility. Amnesty International. Opinion. 10. 10. 2018. [online] [20-01-2019]. Available at: https://hrij. amnesty.nl/remoteness-command-responsibility-icc/

Making Sense of Command Responsibility. Amnesty International. Opinion. 8. 10. 2018. [online] [22-01-2019]. Available at: https://hrij.amnesty.nl/making-sense-of-command-responsibility-bemba/

BITTI, Gilbert. Article 21 of the Statute of the International Criminal Court and the Treatment of Sources of Law in the Jurisprudence of the ICC. In STAHN, Carsten; SLUITE, Göran (ed). The Emerging Practice of the International Criminal Court. Leiden; Boston: Martinus Nijhoff Publishers, 2009.

Akayesu, ICTR, ICTR-96-4-T, TCH, 2. 9. 1998.

Bemba, ICC, ICC-01/05-01/08 424. Decision Pursuant to Article 61(7)(a) and (b) of the Rome Statute, PTCH II, 3. 7. 2009.

Bemba, ICC, ICC-01/05-01/08 A, ACH, 8. 7. 2018.

Bemba, ICC, ICC-01/05-01/08-2138, TCH, 22. 2. 2012.

Bemba, ICC, ICC-01/05-01/08-3121-Red, Defence, 22. 4. 2016.

Bemba, ICC, ICC-01/05-01/08-3343, TCH III, 21. 3. 2016.

Bemba, ICC, ICC-01/05-01/08-3636-Anx1-Red, ACH, 8. 7. 2018.

Bemba, ICC, ICC-01/05-01/08-3636-Anx2, ACH, 8. 7. 2018

Bemba, ICC, ICC-01/05-01/08-3636-Anx3, ACH, 8. 7. 2018.

Hadžihasanović/Kubura, IT-01-47-A, ICTY, ACH, 22. 4. 2008.

Kajelijeli, ICTR, ICTR-98-44A-T, TCH, 1. 12. 2003.

Limaj et al., ICTY, IT-03-66-T, TCH, 30. 11. 2005.

Mucić at al., ICTY, IT-96-21-A, ACH, 20. 2. 2001.

Mucić et al., ICTY, IT-96-21-T, TCH, 16. 11. 1998.

Semanza, ICTR, ICTR-97-20-T-15-5-2003, ICTR, TCH, 15. 3. 2003.

Štrugar, ICTY, IT-01-42-T, TCH, 31. 1. 2005. 